\title{
На пути к более эффективному сотрудничеству? Роль государств в формировании взаимодей- ствия и сотрудничества между НАТО и ЕС
}

\section{Тинатин Агниашвили}

Министерство обороны Грузии

Резюме: Эффективное сотрудничество между Европейским Союзом (ЕC) и Организацией североатлантического договора (НАТО) не только желательно, но даже обязательно в этом взаимозависимом и взаимосвязанном мире. Современные многосторонние угрозы и вызовы безопасности уменьшили значение национальных границ и сделали членов обеих институций почти одинаково уязвимыми. Благодаря органическому сходству между этими организациями, распределение бремени воспринимается как естественное. Однако, существующие рамки сотрудничества оставляют место для существенного улучшения. В этой статье рассматриваются факторы, ограничивающие эффективное сотрудничество между организациями, и сделан анализ на основе изучения поведения отдельных государств (членов обеих организаций или одной из них) при формировании взаимодействия между институциями. В работе анализируется роль ЕС и НАТО в период ливийского кризиса в соседстве с Европой и их взаимодействие в Афганистане - за пределами Евроатлантического региона. Результаты анализа показывают, что некоторые из государств, которые не являются одновременно членами обеих организаций, “держат институции в заложниках»; ${ }^{1}$ фрагментированные позиции государств, являющихся одновременно членами обеих организаций, мешают выработке целостной политики ЕС для кризисного менеджмента (ОПБО), и в итоге, замедляют формирование совместной стратегической концепции ЕС-НАТО. Кроме того, отсутствие разделения труда на местах приводит к дублированию в некоторой степени функций, и сотрудничество между институциями оказывается более эффективным на оперативном, чем на стратегическом уровне.

1 Jolyon Howorth, Security and Defence Policy in the European Union (London: Palgrave Macmillan, 2014), 130. 
Ключевые слова: НАТО, Европейский Союз, политика безопасности, Ливия, сотрудничество НАТО-ЕС.

\section{Введение}

В $21^{\text {-ом }}$ веке международная система сталкивается с исключительно динамическими, многосторонними и комплексными угрозами и вызовами, для ответа на которые требуется комплексный и целостный подход. Нет чисто военных или чисто гражданских решений проблем; сочетание и рациональное использование существующих способностей институциями и государствами, по всей видимости, является единственной возможностью, ведущей к более мирному миру.

Поэтому, изучение взаимодействия между такими двумя ключевыми институциями, как НАТО и ЕС, во взаимосвязанном мире является критически важным, поскольку они играют важную роль в архитектуре глобальной безопасности. В этой статье основное внимание уделяется анализу отношений между Общей политики безопасности и обороны (ОПБО) ЕС и HATO.

Имеются органически присущие сходства между этими двумя организациями, которые естественным путем подталкивают их к сотрудничеству и способствуют общественному восприятию распределения бремени: обе организации разделяют так называемые "Западные ценности», ассоциируемые с демократическими нормами и принципами; стакиваются со схожими многомерными угрозами и вызовами безопасности; применяют комплексный подход в сфере менеджмента кризисов, проводят операции в одних и тех же странах по всему свету; отвечают за европейскую безопасность, и что наиболее важно, имеют двадцать два общих члена из всех двадцати восьми государств. ${ }^{2}$

ЕС и НАТО прошли через разные стадии сотрудничества после 1990-х годов. Динамика их отношений показывает, что их сотрудничество в начале 2000-х было более плодотворным, чем в последующие годы. В 2003 году было финализировано соглашение «Берлин плюс» (позволяющее ЕС использовать активы НАТО в операциях по менеджменту кризисов) и переведено на практические рельсы проведением двух успешных операций на Балканах. ${ }^{3}$ С тех пор институциональное сотрудничество не стало более разнообразным ни в рамках соглашения «Берлин плюс», ни вне их.

В официальных документах институции характеризуют свои отношения как «стратегическое партнерство»; на практике НАТО и ЕС имеют общие стратегические интересы, но без общей стратегической повестки дня.

2 "Montenegro is in the process of joining NATO," по состоянию на 11 октября 2016, http://www.nato.int/cps/en/natohq/topics_49736.htm.

3 “About CSDP - The Berlin Plus Agreement," по состоянию на 17 апреля 2016, http://eeas.europa.eu/csdp/about-csdp/berlin/index_en.htm.

4 “Wales Summit Declaration, 5 September, 2014," по состоянию на 1 апреля 2016, http://www.nato.int/cps/en/natohq/official_texts_112964.htm. 
Как констатировал Херман Ван Ромпей, бывший президент Европейского Совета, «способность наших двух организаций формировать будущую среду безопасности была бы огромной, если бы они работали вместе. Настало время разрушить остающиеся между ними стены». ${ }^{5}$ В этой работе будет проанализировано, почему эти «остающиеся стены» все еще существуют, и почему эти организации не очень успешно сочетают свои усилия в поддержку международного мира и стабильности рациональным, эффективным в смысле расходов и взаимовыгодным способом.

Следовательно, в статье будет сделана попытка ответить на следующий вопрос: какие факторы ограничивают эффективное сотрудничество между EC и HATO?

Отношения НАТО-ЕС являются комплексным феноменом, и поэтому их нельзя рассматривать, ограничиваясь межинституциональным двусторонним форматом; их сотрудничество определяется в наибольшей степени многосторонней динамикой, оркестрированной конкретными странами. Поэтому взаимодействие ЕС-НАТО будет проанализировано скорее с точки зрения отдельных стран (членов двух, или одной из этих организаций), чем в разрезе самих институций.

В статье будут рассмотрены следующие гипотезы: 1. Некоторые из стран, не являющихся членами обеих организаций, «держат институции в заложниках»; ${ }^{6}$ 2. Расхождение позиций стран, членов обеих организаций, в отношении ОПБО ЕС, способствует тому, что отсутствует общая НАТО-ЕС стратегическая концепция. Оба эти обстоятельства подрывают эффективное сотрудничество институций.

Как было уже упомянуто, НАТО и ЕС имеют двадцать два общих члена, а двенадцать государств ${ }^{7}$ остаются только в одной институциональной рамке (смотри Приложение А). Это несимметричное членство оказывает разное влияние на отношения НАТО-ЕС: некоторые из недвойных членов играют более позитивную роль (Канада, Швеция, Финляндия, Норвегия), тогда как другие способствуют ограничению сотрудничества.

Благодаря большому числу и сложному взаимодействию между недвойными членами, данное исследование будет сосредоточено на Турции и Кипре, которые постоянно и в значительной степени оказывают влияние на отношения организаций из-за своих политических споров.

Среди недвойных членов примечательна так же роль США, однако, поскольку позиция США в отношении политики безопасности и обороны ЕС

5 "Remarks by Herman Van Rompuy, President of the European Council," Lisbon Summit, 2010, по состоянию на 20 января 2016, www.consilium.europa.eu/uedocs/ cms_data/docs/pressdata/en/ec/117890.pdf.

6 Howorth, Security and Defence Policy in the European Union, 130.

7 "Members of NATO and not EU," http://www.nato.int/cps/en/natolive/topics_ 52044.htm; http://europa.eu/about-eu/countries/member-countries/, по состоянию на 17 января 2016. 
развивалась с течением времени - от скептицизма к необходимости распределения бремени, она не попадает напрямую в охват данной статьи.

В работе будут так же рассмотрены расходящиеся позиции двойных членов этих институций и изложено мнение, что нежелание европейских стран разработать целостную и когерентную ОПБО имеет отрицательные последствия для взаимодействия ЕС-НАТО. Разделение между двойными членами, между так называемыми "Атлантистами» 8 и "Европеистами», является основой для серьезного различия приоритетов во внешней политике и политике безопасности.

Раздробленная позиция европейских государств в рамках ОПБО является основной причиной проблем между институциями и неизбежным обстоятельством, порождающим необходимость сотрудничества.

В статье анализируются отношения между ЕС и НАТО в Афганистане и Ливии, которые являются двумя абсолютно разными случаями; тем не менее, они дают комплексную картину взаимодействия между этими институциями на разных уровнях, в разных местах и в разных условиях.

Соответственно представлена и структура данной работы: на первом месте, будет очерчена существующая институциональная рамка сотрудничества между ЕС и НАТО; на втором, будет рассмотрена роль Турции и Кипра в формировании поведения этих организаций; в третьих, будут рассмотрены отношения между институциями в Афганистане и четвертое, будут исследованы результаты работы этих организаций во время ливийского кризиса, и таким образом поставлен вопрос об адекватности соглашения «Берлин плюс».

\section{Методология}

Как было отмечено, данная статья ограничена до анализа влияния Турции и Кипра на отношения НАТО-ОПБО из-за политических споров между этими странами и так называемого «право на вето», которое они используют в этих институциях. Кипр является единственной страной среди недвойных членов ЕС, которая не участвует в программе НАТО «Партнерство ради мира» и потому не имеет соглашения с Альянсом по безопасности. ${ }^{9}$

В исследовании рассматриваются отношения между ЕС и НАТО в Афганистане, за пределами Евроатлантического региона, и во время ливийского кризиса, в непосредственной близости от Европы.

В случае с Афганистаном обе организации одновременно присутствовали на театре операции, направленной на подготовку афганских полицейских сил; выполнялись небоевые миссии, и предварительным условием была руководящая роль НАТО в среде безопасности. Срочность со-

8 Howorth, Security and Defence Policy in the European Union, 120.

9 Stephanie C. Hofmann, "Overlapping Institutions in the Realm of International Security: The Case of NATO and ESDP," Perspectives on Politics 7, no. 1 (March 2009): 4552, цитата на стр. 46. 
Роль государств в формировании взаимодействия между НАТО и ЕС

\begin{tabular}{|l|l|}
\multicolumn{1}{|c|}{ Ливия } & \multicolumn{1}{c|}{ Афганистан } \\
\hline Недалеко от Европы & $\begin{array}{l}\text { За пределами Евроатлантического } \\
\text { региона }\end{array}$ \\
\hline Угроза для Европы & Нет прямой угрозы \\
\hline Военная операция - в начале & $\begin{array}{l}\text { Гражданская миссия (ЕС) - миссия } \\
\text { по обучению (НАТО) }\end{array}$ \\
\hline Срочность & Нет срочности \\
\hline $\begin{array}{l}\text { Ни одна из организаций не } \\
\text { присутствует }\end{array}$ & Обе организации присутствуют \\
\hline
\end{tabular}

здания миссии в Афганистане была низкой по сравнению с миссией в Ливии.

В случае с Ливией кризис имел место на пороге Европы, что подвергало ЕС опасности с южной стороны. Кроме того, существовало ощущение срочности: ЕС, НАТО и отдельные государства чувствовали себя обязанными своевременно предпринять конкретные меры; предполагалось, что в свете своих больших амбиций и с целью укрепить ОПБО ЕС осуществит военную операцию, тогда как НАТО не имело желания принимать участие в событиях в Ливии и в итоге, ни одна из этих организаций не была на месте, когда разразился кризис.

Исследование этих конкретных случаев дает твердую основу для анализа особенностей отношений институций по вопросам обороны и безопасности и выявляет некоторые межинституциональные проблемы и недостатки в рамках ОПБО.

\section{Существующая рамка сотрудничества}

В развитии отношений НАТО-ОПБО можно указать на два краеугольных камня: начавшееся в 1998 году стремление Европы достичь автономии в измерениях безопасности и обороны, и подписание соглашения «Берлин плюс» в 2002 году.

Сначала НАТО, и в частности США, были настроены скептически к Декларации Сен-Мало (франко-британский саммит, 1998), ${ }^{10}$ в которой заявлялось, что «Союз должен располагать потенциалом для автономного действия, подкрепленным надежными вооруженными силами», и которая привела к созданию Общей европейской политики безопасности и обороны (ОПБО). ${ }^{11}$ Основной причиной было опасение, что будет иметь место

10 Общая декларация франко-британского саммита, Сен Мало, Франция, 3-4 декабря 1998.

11 Jolyon Howorth and John T.S. Keeler, Defending Europe: The EU, NATO and the Quest for European Autonomy (New York: Palgrave Macmillan, 2003), 10. 
дублирование активов НАТО, что приведет к потенциальному соперничеству.

Здесь интересна позиция Соединенного Королевства, которое считали наиболее "атлантическим» союзником среди двойных членов. Соединенное Королевство поддерживало развитие европейской “военной ветви», чтобы держать в поле зрения ОПБО и гарантировать, что ее развитие не войдет в противоречие с интересами НАТО.

Первоначальная подозрительность США нашла выражение в «трех Д» ${ }^{12}$ государственного секретаря Мадлен Олбрайт, дававших зеленый свет ОПБО при условии, что не будет никакого деления, никакого дублирования и никакой дискриминации. В 2000 году позиция США была сформулирована более категорично в виде заявления, что «когда речь идет о военной силе, НАТО остается их первым выбором». ${ }^{13}$

В последующие годы скептицизм США был заменен пониманием большой необходимости в распределении бремени и в развитии сильных европейских военных способностей, которые усилят НАТО, а не будут конкурировать с ним. ${ }^{14}$ Европу подталкивали к принятию на себя большей ответственности в поддержание мира и безопасности в рамках своих границ, чтобы можно было вывести войска США из Европы.

Параллельно, НАТО и ЕС вели операции и осуществляли миссии в разных частях мира. Имеются существенные различия в военных (человеческих ресурсах, логистике) и оперативных (структурных) способностях этих организаций. Это нельзя рассматривать в качестве фактора, подрывающего сотрудничество, как раз наоборот, поскольку они создают основу для распределения бремени между ними.

В отличие от НАТО, у ЕС нет постоянного оперативного штаба для эффективного проведения военных операций. Из-за того, что ЕС не располагает способностью для стратегического планирования, воплощенной в военном персонале и постоянной штаб-квартире, ${ }^{15}$ миссии ОПБО организуются ад-хок штабами.

Единственной институциональной юридической рамкой для сотрудничества (на стратегическом уровне) между этими организациями является соглашение «Берлин плюс» от 2003 года, ${ }^{16}$ позволяющее ЕС использовать ресурсы и способности НАТО для операций по менеджменту кризисов.

Заключение этого соглашения между ЕС и НАТО отняло три года на проведение сложнейших переговоров. Одной из ключевых причин для

12 Howorth, Security and Defence Policy in the European Union, 112.

13 Там же, 113. Филип Гордон, бывший директор по европейским делам Совета национальной безопасности.

14 John Baylis and Jon Roper, The United States and Europe (New York: Routledge, 2006), 120.

15 Там же, 34.

16 Martin Reichard, The EU-NATO Relations: A Legal and Political Perspective (Alder-shot, Burlington: Ashgate Publishing Company, 2006), 275. 
бесконечных раундов консультаций была позиция Турции, ${ }^{17}$ которая боялась, что когда будет достигнуто согласие по политике предоставления взаймы активов, ее интересы в области национальной безопасности вблизи ее границ подвергнутся опасности. В конце концов, Турция позволила достижение соглашения при выполнении конкретных условий: ${ }^{18}$ ОПБО не будет использоваться против союзников НАТО, «Берлин плюс» будет действовать только в отношении двойных членов ЕС и НАТО и сторон по программе «Партнерство ради мира», имеющих двусторонние соглашения по безопасности с Альянсом, Кипр (и Мальта) не будет участвовать в операциях в рамках соглашения «Берлин плюс» после того, как он станет членом ЕС. Соглашение было подписано в декабре $2002,{ }^{19}$ и Кипр стал членом ЕС в мае $2004^{20}$ в рамках большой волны расширения.

Другой причиной для начала работы соглашения «Берлин плюс» была сильная надежда Турции на сближение с ЕС. В 2002 году Греция смягчила свою позицию по членству Турции в этой организации, и ЕС поставил срок для начала переговоров по вступлению Турции в декабре $2004 .^{21}$ Следующие годы ясно показали, что эти процессы были не очень успешными, и причины для не реактивации соглашения «Берлин плюс» вероятно связаны и с этим фактом.

Дополнительными и наиболее важным фактором, проложившим путь к соглашению, была единая позиция европейских стран по восприятию угрозы, исходящей со стороны Балкан, сильная необходимость предпринять конкретные меры и готовность США уйти из Европы и мобилизовать свои войска для развертывания на Востоке.

С начала действия соглашения «Берлин плюс» были предприняты две операции в его рамках: военная операция (Конкордия) в Бывшей Югославской Республике Македония в 2003 году ${ }^{22}$ и вторая военная операция (Алтея) в Боснии и Герцеговине с 2004 года, которая является единственной продолжающейся операцией под эгидой «Берлин плюс».

На оперативном уровне институции смогли организовать более эффективную рамку для сотрудничества, чем на стратегическом уровне. В 2005 году при Военном штабе ЕС была учреждена Постоянная группа по связям с НАTO, ${ }^{23}$ а с 2006 года при Штаб-квартире вооруженных сил НАТО в Ев-

17 Там же, 287.

18 Там же.

19 Reichard, The EU-NATO Relations: A Legal and Political Perspective, 275.

20 “EU member countries," по состоянию на 3 марта 2016, http://europa.eu/abouteu/countries/member-countries/index_en.htm.

21 Reichard, The EU-NATO Relations: A Legal and Political Perspective, 287.

22 “Mission Description," по состоянию на 3 марта 2016, www.eeas.europa.eu/ archives/csdp/missions-and-operations/concordia/mission-description/index_ en.htm.

23 "NATO-EU: Strategic Partnership, Framework for Cooperation," по состоянию на 26 февраля 2016, http://www.nato.int/cps/en/natohq/topics_49217.htm. 
ропе начала функционировать Ячейка ЕС. Таким образом, соглашение «Берлин плюс» дает ЕС уникальную возможность использовать уже существующие структуры Альянса для операций по менеджменту кризисов.

В эпоху жестких экономий обе организации поняли значение общего пользования способностей, но на внутриинституциональном, а не на межинституциональном уровне: НАТО разработало инициативу «Умная оборона», $^{24}$ а ЕС - инициативу по объединению ресурсов и совместному использованию средств. ${ }^{25}$ Поэтому нежелание организаций использовать сообща ресурсы приводит к приобретению дополнительных способностей, и в определенной степени, к дублированию их функций.

Другим критически важным фактором является двойная ответственность членов обеих организаций. Они обязаны давать свой вклад по отдельности как в операции НАТО, так и в операции ЕС. Двойным членам иногда приходится делать выбор между деятельностями организаций, что приводит к вкладам на принципе «нулевой суммы», и «в мире сокращающихся ресурсов каждый понимает, что европейские силы и способности, развертываемые через НАТО или через ОПБО, берутся из одного и того же источника». ${ }^{26}$

Вот почему существующие правовые рамки сотрудничества НАТО-ЕС позволяют организациям сообща использовать свои способности и вести успешные операции при наличии политической воли.

\section{Роль недвойных членов в формировании взаимодействия институций}

\section{Турция и Кипр}

Политический спор между Турцией и Кипром является ярким примером того, как отдельные страны, недвойные члены, могут оказывать большое влияние на отношения между институциями. Нерешенные проблемы между Турцией и Грецией, касающиеся воздушного пространства над Эгейским морем, территориальных вод и разделенного острова Кипр, ${ }^{27}$ являются основными причинами для напряженности в отношениях между этими странами.

Асимметричные членства Турции (член НАTO, но не ЕС) и Кипра (член ЕC, но не НАТО) и «право на вето» (в рамках ОПБО и НАТО) являются ключевыми факторами, способствующими ограничению сотрудничества между институциями. Как отметил представитель Франции в штаб-квар-

\footnotetext{
24 “Smart Defence," по состоянию на 9 января 2016, www.nato.int/cps/en/natohq/ topics_84268.htm.

25 “EDA's Pooling and Sharing," по состоянию на 9 января 2016, www.eda.europa.eu/ docs/default-source/eda-factsheets/final-p-s_30012013_factsheet_cs5_gris.

26 Howorth, Security and Defence Policy in the European Union, 141.

27 Там же, 131.
} 
тире союзных сил в Европе (SHAPE), отношения между ЕС и НАТО напоминают «игру в кошки-мышки», в которой каждый обвиняет другого, и в конце концов они должны «как-то» взаимодействовать. ${ }^{28}$

Первоначальный скептицизм Турции к ОПБО предопределил более сложные отношения с ЕС после принятия Кипра в 2004 году. ${ }^{29}$ Турция боялась развития военных способностей ЕС по двум главным причинам: угроза быть исключенной из архитектуры европейской безопасности, в частности, Турция имеет слабое влияние на формирование стабильности в непосредственном соседстве, лишена права участвовать в процессе принятия решений Комитета по политическим вопросам и вопросам безопасности (КПБ) в отличие от важной роли, занимаемой ею в Западноевропейском союзе (ЗЕС); и нежелание ЕС рассматривать принятие Турции.

Сразу после того, как Кипр стал членом ЕС, между этими двумя странами началась «игра в вето», что привело к ограничению возможных областей сотрудничества между организациями. ${ }^{30}$

Из-за кипрского вето, Турция встречается с препятствиями при участии или консультациях, касающихся миссий ОПБО, в отличие от ситуации с операциями под эгидой ОПБО раньше: Турция была третьим самым большим участником в операции «Алтея» в Боснии и Герцеговине, и даже выразила свою готовность участвовать в Оперативных боевых группах ЕC; ${ }^{31}$ Кипр заблокировал участие Турции в Европейском оборонном агентстве (EOA). ${ }^{32}$ ЕС отказался подписывать соглашение с Турцией об обмене секретной информацией. Более того, Кипр тормозит турецкие амбиции по присоединению к ЕС. ${ }^{33}$

Со своей стороны, Турция запретила предоставление разведывательной информации НАТО ЕС, ограничила попытки обсуждать вопросы, выходящие за рамки соглашения «Берлин плюс», и помешала официальному и неофициальному участию Кипра в сотрудничестве ЕС-НАTO. ${ }^{34}$

Bсе эти годы люди, принимающие решения на самых высоких постах, вкладывали большие усилия в преодоление «политики вето», но все круги

28 Французский представитель в Штаб-квартире союзных сил в Европе, интервью с автором, Тинатин Агниашвили, Женева, Швейцария, март 2016.

29 Richard Whitman and Stefan Wolff, The European Union as a Global Conflict Manager (New York: Routledge, 2012), 53.

30 Бельгийский представитель в Штаб-квартире НАТО, интервью с автором, Тинатин Агниашвили, Женева, Швейцария, март 2016.

31 Adam Szymanski and Marcin Terlikowski, "The Policy of Turkey towards EU-NATO Cooperation" (Warsaw: The Polish Institute of International Affairs, 2010).

32 Howorth, Security and Defence Policy in European Union, 132.

33 Kashmeri, The North Atlantic Treaty Organization and the European Union's Common Security and Defense Policy: Intersecting Trajectories, 33.

34 Münevver Cebeci, "NATO-EU Cooperation and Turkey," Turkish Policy Quarterly 10, nо. 3 (2011): 93-103, 100, по состоянию на 11 марта 2016, http://turkishpolicy.com/pdf/vol_10-no_3-cebeci.pdf. 
переговоров не привели к успеху. ${ }^{35}$ В 2010 году Генеральный секретарь НАТО предложил заключить соглашение между ЕС и Турцией, которое позволило бы институциям выйти из тупика, ${ }^{36}$ и согласно которому предполагался обмен классифицированной информацией, участие Турции в EOA и участие Кипра в деятельности обеих организаций на техническом уровне. Однако, проведенные раунды консультаций снова не привели к результатам.

Являясь ключевой силой в рамках НАТО, Турция получает широкую поддержку со стороны США. Стратегическое значение Турции для США существенно увеличилось после террористических нападений 11 сентября 2001 года, за которыми последовала военная операция в Афганистане. ${ }^{37}$ Участие этого мусульманского государства в антитеррористической коалиции было оценено очень высоко; однако, США не имеют прямого влияния на решения $\mathrm{EC}$.

Основываясь на этом анализе, можно прийти к заключению, что Турция и Кипр оказывают влияние на сотрудничество между ЕС и НАТО и, как и предполагает первая гипотеза в этой статье, «держат институции в заложниках». $^{38}$

Однако, проблемы стратегического сотрудничества ЕС-НАТО не ограничиваются применением Турцией и Кипром их «права на вето». Картина является гораздо более сложной и комплексной и проистекает от расхождения позиций стран двойных членов.

\section{Подготовка полиции в Афганистане}

Афганистан является интересным местом для рассмотрения отношений между ЕС и НАТО по двум причинам: обе организации участвовали в операции вне территории трансатлантического региона, выполняя свои обязанности одновременно; обе организации имеют долгосрочные ангажементы к Афганистану и нуждаются взаимно в способностях друг друга для успешного достижения поставленных целей.

Поэтому Афганистан дает уникальную возможность для расширенного сотрудничества, а также дает возможность выявить слабости взаимодействия между институциями на стратегическом, оперативном и тактическом уровне.

Изучение данного конкретного случая, в частности, сосредоточено на взаимодействии между ЕС и НАТО в Афганистане за время с 2007 по 2014

35 Представитель международной администрации НАТО, интервьюированный автором Тинатин Агниашвили, Женева, Швейцария, март 2016.

36 Szymanski and Terlikowski, "The Policy of Turkey towards EU-NATO Cooperation," 2010.

37 Howorth and Keeler, Defending Europe: The EU, NATO and the Quest for European Autonomy, 113.

38 Howorth, Security and Defence Policy in the European Union, 130. 
год, когда обе институции наряду с другими обязанностями на месте принимали участие в подготовке Афганской национальной полиции (АНП). С 2007 года ЕС выполняет в Афганистане гражданскую Полицейскую миссию (ЕУПОЛ) в рамках ОПБО. ${ }^{39}$ Мандат этой миссии был продлен до декабря 2016 года. $^{40}$

Параллельно с этим, в период 2009-2014 НАТО проводило Учебную миссию в Афганистане (НУМ-А), ${ }^{41}$ чей основной целью была подготовка рекрутов и создание институционального потенциала для обучения Афганских сил безопасности (Афганской национальной армии и Афганской национальной полиции (АНП)).

Большая численность АНП (к концу 2014 года численность АНП достигла $153000)^{42}$ ясно указывала на необходимость разделения бремени между организациями и на важность целостного подхода.

\section{Слишком большое международное присутствие и плохая координация}

Благодаря факту, что одним из первейших приоритетов афганского государства является развитие профессиональных полицейских сил, международное сообщество было очень активным в обеспечении поддержки в этой сфере как на двустороннем, так и на многостороннем уровне.

В течение 13 лет более 27 международных доноров (государства и организации) принимали участие в оказании помощи реформированию афганской полиции, большинство из них участвовали в ЕУПОЛ, НУМ-А или в обеих миссиях. ${ }^{43}$ В число ключевых акторов, выполняющих свои обязательства одновременно, входят ООН, ЕС, НАТО, США и Германия. После конференции ООН в 2002 по вопросам реформирования сектора безопасности в Афганистане руководство оказания помощи афганским полицейским силам приняла на себя Германия. ${ }^{44}$ Более того, для облегчения эффективной координации иностранной помощи в 2007 году был учрежден Международный полицейский координационный совет, но существенного прогресса не было. ${ }^{45}$

39 “What is EUPOL Afghanistan," по состоянию на 1 марта 2016, http://www.eupolafg.eu/node/37.

40

Там же.

41 “NATO and Afghanistan," по состоянию на 1 марта 2016, www.nato.int/cps/en/ natohq/topics_8189.htm.

42 Там же.

43 European Court of Auditors, "The EU Police Mission in Afghanistan: Mixed Results," Special Report no. 7 (Luxembourg: Publications Office of the European Union, 2015), 19, по состоянию на 1 марта 2016, www.eca.europa.eu/Lists/ECADocuments/ SR15_07/SR_EUPOL_AFGHANISTAN_EN.pdf.

44 Eva Gross and Ana E. Juncos, EU Conflict Prevention and Crisis Management: Roles, Institutions, and Policies (New York: Routledge, 2011), 121.

45 European Court of Auditors, "The EU Police Mission in Afghanistan," 19. 
Наряду с многочисленностью акторов, имели место недостатки в руководстве и недостаточная координация при синхронизации помощи доноров. Из-за отсутствия когерентной политики в многомерной среде, осуществление реформы афганской полиции стало очень сложным, что привело к введению разными донорами разных видов учебной подготовки (иногда противоречивых и менее эффективных). ${ }^{46}$

Поэтому, с одной стороны, многочисленность доноров на месте можно рассматривать как преимущество, но с другой - при отсутствии координационного механизма и в жесткой среде безопасности - это может создавать существенные проблемы для принимающего государства и может привести к нерациональному использованию внешних ресурсов.

\section{Внутренние и внешние вызовы для ЕУПОЛ}

Присутствие ЕС в перенаселенном международном ландшафте Афганистана с самого начало было отмечено неопределенностью. Создание ЕУПОЛ в большой степени было обусловлено давлением Германии (в качестве лидирующего государства), направленным на ускорение реформы полиции под эгидой ЕС, и готовностью США участвовать в распределении бремени. ${ }^{47}$

Вызовы перед миссией ЕУПОЛ в Афганистане можно резюмировать следующим образом: нехватка человеческих ресурсов, логистических способностей и четкого руководства, недостаточное финансирование, некогерентность институций ЕС, предпочтение государств ЕС к участию в других миссиях, лишение небольших вкладчиков права выполнять координационную функцию, жесткая среда безопасности, высокий уровень неграмотности в афганских полицейских силах и отсутствие стратегического соглашения с НАТО, отвечающего за обеспечение безопасности на месте.

Хотя Совет принял решение инициировать ЕУПОЛ, члены ЕС демонстрировали нежелание способствовать данной миссии. Два месяца после принятия решения Советом, ЕУПОЛ располагала всего четырьмя административными сотрудниками, действующими в Кабуле. ${ }^{48}$ Процесс развертывания затягивался и так никогда и не достиг порога требуемых человеческих ресурсов: первоначальный план развертывания 200 экспертов не был выполнен до 2009 года (после двух лет), и хотя в 2008 году Совет решил удвоить персонал до 400 сотрудников, максимальное число сотрудников к 2012 году достигло всего $350 .{ }^{49}$ Хотя число участвующих в ЕУПОЛ членов ЕС со временем увеличилось, ${ }^{50}$ объем их

46 Whitman and Wolff, The European Union as a Global Conflict Manager, 112.

47 Panos Koutrakos, The EU Common Security and Defense Policy (Oxford: Oxford University Press, 2013), 147.

48 European Court of Auditors, "The EU Police Mission in Afghanistan," 15.

49 Там же, 16.

5019 ЕС государств в 2009, 22 государства в 2010, 23 государства в 2012. См. House of Lords, "The EU's Afghan Police Mission," London, 2011; "EUPOL Afghanistan, 
вкладов оставался очень маленьким и не оказал большого влияния на успешное выполнение миссии. Важным фактором является то, что Канада и Норвегия (являющиеся членами НАТО, но не ЕС) тоже включились в ЕУПОЛ ${ }^{51}$ и показали, что недвойные члены так же могут быть надежными партнерами.

ЕУПОЛ не была очень успешной при рекрутировании прикомандированного персонала из-за конкуренции с другими миссиями ОПБО, НУМ-А и миссиями ООН. ${ }^{52}$ Кроме того, на доверие к миссии еще большее отражение давали проблемы руководства и логистические проблемы. В течение первых восемнадцати месяцев руководитель миссии менялся три раза. ${ }^{53}$ Другим препятствием было отсутствие четкого руководства миссии ЕУПОЛ и ее функций со стороны Брюсселя. Мандат миссии регулярно адаптировался к меняющимся приоритетам и к ситуации на месте. ${ }^{54}$ Этот факт продемонстрировал недостатки общей и когерентной политики гражданской миссии ОПБО в Афганистане.

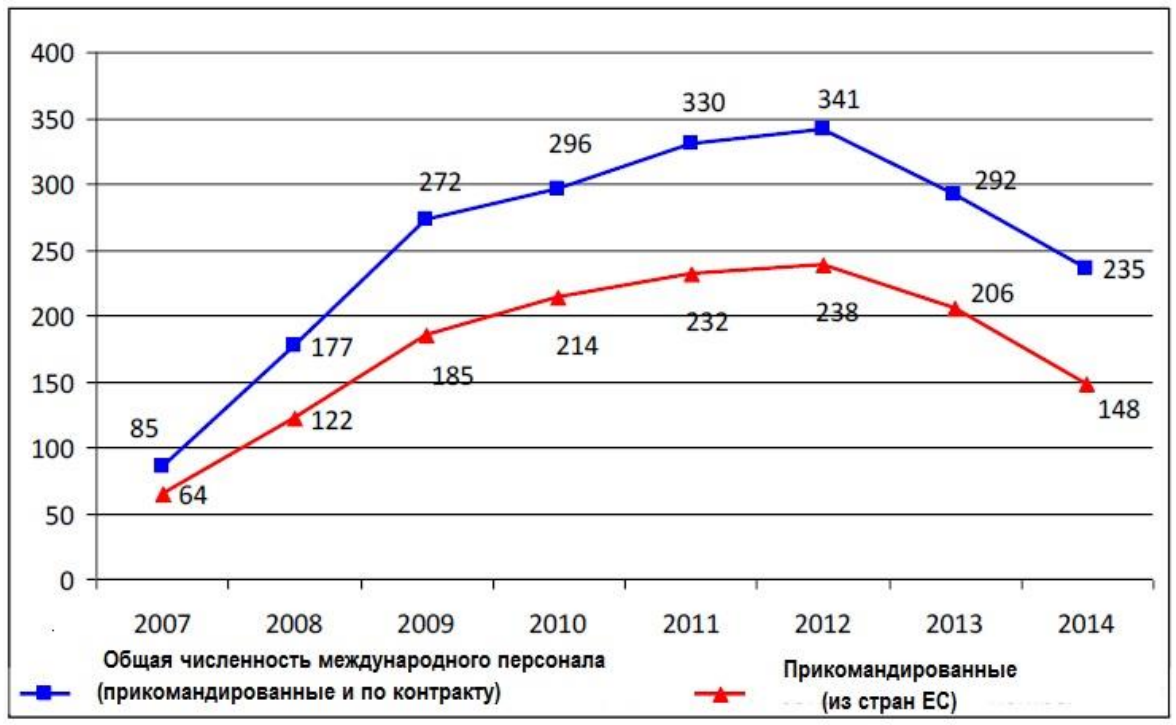

Фигура 1: Общая численность международного (прикомандированного и работающего по контракту) и прикомандированного из ЕС персонала ЕУПОЛ к 31 декабря каждого года с 2007 по 2014 год.

Источник: EEAS (CPCC).

Factsheet," по состоянию на 22 апреля 2016, http://moi.gov.af/Content/files/ eupol-eng-factsheet.pdf.

51 Там же.

52 European Court of Auditors, "The EU Police Mission in Afghanistan," 17.

53 Там же, 5.

54 Там же, 8. 
Более того, ЕУПОЛ выявила институциональные проблемы и недостаточную координацию между органами ЕC, работающими в Афганистане и вне его границ. Отсутствие финансирования миссии можно отнести за счет слабого взаимодействия между ЕУПОЛ и Европейской комиссией, которая отвечает за сбор средств. ${ }^{55}$

Одной из дополнительных задач ЕУПОЛ было осуществление координации международных усилий, направленных на содействие реформе афганской полиции. ${ }^{56}$ ЕУПОЛ не успела выполнить эту задачу и свести вместе европейские акторы в единую рамку, ${ }^{57}$ хотя она способствовала улучшению сотрудничества между членами ЕС на месте.

Другим важным препятствием для ЕУПОЛ был факт, что многие странычлены ЕС продолжали заниматься предпочитаемыми ими деятельностями в Афганистане в рамках двустороннего формата. ${ }^{58}$ Конкретные государства хотели сохранить свое влияние в конкретных направлениях в качестве отдельного государства, а не члена вопросных организаций.

Недостатки миссии ЕУПОЛ можно отнести за счет не только внутренних, но и внешних факторов: сложная среда безопасности на месте, неэффективная координация между международными донорами и высокий уровень неграмотности среди сил афганской полиции (до $80 \%)^{59}$ мешали успешной реализации поставленных целей.

Однако, целостную роль ЕУПОЛ в Афганистане не следует недооценивать. ЕУПОЛ успела добиться конкретных результатов. По мнению Европейского суда аудиторов, ${ }^{60}$ ЕУПОЛ оказалась в некоторой степени эффективной при выполнении своего мандата: миссия была более успешной в деятельности, связанной с подготовкой, и менее успешной при осуществлении наставничества и при консультировании. После того, как были выявлены недостатки, перед ЕС стояла задача разработать подробное руководство для миссий ОПБО. Имел место прогресс в создании концептуальной базы Министерства внутренних дел, разработке курсов обучения и создании Штабного колледжа полиции в качестве ключевой учебной институции. ${ }^{61}$ К концу 2014 года, ЕУПОЛ провела 1400 курсов подготовки с 31000 обучающихся. ${ }^{62}$

Следовательно, создание гражданской миссии ОПБО в Афганистане было политическим решением, инициированным отдельной европейской

\footnotetext{
55 Koutrakos, The EU Common Security and Defense Policy, 148.

56 Там же.

57 European Court of Auditors, "The EU Police Mission in Afghanistan," 8.

58 Там же, 18.

59 Там же, 15.

60 Там же, 7.

61 Там же, 23.

62 Там же, 24.
} 
страной - Германией. В Афганистане четко было продемонстрировано верховенство интересов отдельных стран над целями институций.

\section{Взаимодействие НАТО-ЕС - комплексная мозаика}

Отношения НАТО-ЕС в Афганистане своими меняющимися аспектами напоминают сложную мозаику. Отношения между институциями, в частности, рассматриваемыми через призму обучения афганской полиции, стартовали в позитивном ключе. Альянс подталкивал ЕС к внесению своего вклада в развитие Афганистана и проложил путь к учреждению миссии ЕУПОЛ в 2007 году. ${ }^{63}$

В ходе проведения самой большой и наиболее сложной операции в своей истории - Международных силах содействия безопасности (МССБ) Альянс осознал дальнейшую необходимость в привлечении гражданских способностей. Целью первой операции Альянса "вне своих границ» было обеспечение безопасности и оказание помощи правительству Афганистана в строительстве профессиональных афганских сил безопасности. ${ }^{64}$ Большая численность военных частей, развернутых на месте, не могла гарантировать успех операции из-за многомерного характера проблем безопасности. Сотрудничество с гражданским обществом, реализация экономических проектов, гражданское восстановление и, что самое важное, подготовка сил афганской полиции требовали расширения сотрудничества с ЕС.

Необходимость в распределении общего груза вне предела евроатлантического региона стала очевидной, и обе институции на политическом уровне осознали важность предоставления активов в областях, в которых они имели относительное преимущество.

Однако отношения между организациями на театре военных действий четко выявили существующие недостатки, которые можно отнести на счет отсутствия стратегического видения, отсутствия технических соглашений и отсутствия разделения труда. Эти препятствия стали серьезной причиной для дублирования функций, и в итоге привели к предоставлению разных типов подготовки полиции для афганского правительства.

Однажды активированная, ЕУПОЛ должна была сотрудничать с НАТО в качестве основного поставщика безопасности в Афганистане. Кроме соглашения "Берлин плюс» (которое в случае Афганистана не имеет отношения, поскольку ЕУПОЛ является гражданской миссией, а не военной операцией), не было никакого официального соглашения между институциями, которое облегчало бы успешное сотрудничество для взаимных нужд.

63 Stephen Flanagan, T.J. Cipoletti, and Amanda Tuninetti, "Afghanistan: A Stress Test for Transatlantic Security Cooperation," in The Transatlantic Relationship and EUU.S. Cooperation in Security, Report (CSIS, May 2011), по состоянию на 11 марта 2016, https://csis-prod.s3.amazonaws.com/s3fs-public/legacy_files/files/ publication/110501_Flanagan_EUUSSecurity_Issue\%204.pdf, 193.

64 "NATO and Afghanistan." 
Недостаточное сотрудничество на стратегическом уровне оказывает свое влияние на оперативном и на тактическом уровнях. Афганистан не входил в повестку дня встреч между Комитетом по политическим вопросам и вопросам безопасности и Североатлантическим советом. ${ }^{65}$ И это привело к отсутствию совместной стратегической повестки дня.

Между масштабом ЕУПОЛ и НУМ-А имелась существенная разница. ЕУПОЛ была небольшой миссией, которая не могла формировать или оказывать влияние на стратегическую повестку дня в подготовке полиции, тогда как НУМ-А представляла собой миссию большего масштаба с амбицией осуществлять подготовку афганских Сил безопасности. НУМ-А была направлена на сведение подготовки афганской армии и подготовки полиции под одну крышу, ${ }^{66}$ и основной акцент был поставлен на строительство так называемых «сил для борьбы с повстанцами».

ЕУПОЛ была направлена в большей степени на гражданскую полицейскую деятельность, тогда как НУМ-А была ориентирована на строительство полицейских сил более «военного типа», заявляя, что они более подходят для существующей в Афганистане среды. Эти разные подходы привели к противоречивому консультированию и подготовке, предоставляемых Министерству внутренних дел, и этого можно было бы избежать, если бы существовало стратегическое видение по данному вопросу.

На оперативном уровне, необходимость и готовность к сотрудничеству между ЕУПОЛ и НАТО было более видимым. Персоналу ЕУПОЛ, размещенному в Кабуле, 67 региональным командованиям и провинциям была нужна защита на месте, которую обеспечивало НАТО.

Развертывание Провинциальных групп по восстановлению (ПГВ), за которые отвечало НАТО, было приостановлено из-за отсутствия официальной договоренности между институциями. Поэтому, единственно возможным решением было инициировать подписание технических соглашений с отдельными ведущими странами, что оказалось весьма времяемким процессом. Кроме того, Турция не подписала технического соглашения с ЕУПОЛ, и поэтому персонал ЕС не присутствовал в провинциях, контролируемых Турцией.

Более того, из-за отсутствия соглашения ЕС с НАТО по обмену классифицированной информацией, ситуационная осведомленность ЕУПОЛ и операции в опасной оперативной среде были ограничены. ${ }^{69}$ Поэтому, отсутствие стратегической повестки дня не только мешало сотрудничеству между организациями, но затормаживало в определенной степени выполнение мандата ЕУПОЛ.

65 Whitman and Wolff, The European Union as a Global Conflict Manager, 113.

66 "NATO Training Mission."

67 Whitman and Wolff, The European Union as a Global Conflict Manager, 116.

68 European Court of Auditors, "The EU Police Mission in Afghanistan," 17.

69 Flanagan, Cipoletti, and Tuninetti, “Afghanistan: A Stress Test for Transatlantic Security Cooperation," 193. 
В заключение, анализ взаимодействия между ЕС и НАТО в Афганистане выявило несколько важных проблем и привело к важным выводам. Препятствия перед взаимодействием организаций можно отнести на счет отсутствия совместной стратегической повестки дня, технических соглашений и обмена классифицированной информацией; кроме того, вызовы перед миссией ЕУПОЛ показали наличие расходящихся позиций у европейских стран и выявили ряд недостатков ОПБО в качестве конкретного инструмента. Отсутствие разделения работы межу ЕС и НАТО привело к дублированию функций на местах и к предоставлению противоречивого обучения афганскому правительству.

В целом, сотрудничество между ЕС и НАТО вне границ евроатлантического региона, когда предварительная обстановка не требует особой срочности действий, и в невоенных измерениях, не было особенно успешным. НАТО было доминирующим в этих отношениях и соответственно формировало взаимодействие. Однако, очень важно подчеркнуть, что сотрудничество на оперативном уровне было более эффективным и результативным, чем сотрудничество на стратегическом уровне. В рамках существующих нормативных ограничений эти организации сотрудничали в максимально возможной степени и успели добиться такого конкретного результата, как «договоренность совместно учредить Совет по профессиональной подготовке, отвечающий за разработку и аккредитацию программ обучения полицейских». 70

В итоге можно сказать, что результаты анализа случая Афганистана еще раз подчеркивают наличие отличающихся позиций двойных членов (в рамках ЕС) и отсутствие общего стратегического видения, что способствует уменьшению эффективности сотрудничества между организациями.

\section{Ливийский кризис}

Этот раздел посвящен рассмотрению эффективности ЕС и НАТО в ливийском кризисе, обсуждению причин ограниченного межинституционального сотрудничества, а также проблем ОПБО. При этом обнаруживается, что предпочтение отдается национальным интересам в ущерб институциональным потребностям.

Как отметил французский представитель в штаб-квартире союзных сил в Европе (SHAPE), операцию НАTO в Ливии можно определить как «операцию 'Берлин плюс' с использованием способностей Альянса и участием европейских государств, но без ярлыка ЕС». ${ }^{71}$

Поэтому, во время кризиса в Ливии, ожидание и необходимость распределения бремени между ЕС и НАТО при таких существующих юридических рамках, как соглашение «Берлин плюс», были очень высокими. Од-

70 European Court of Auditors, "The EU Police Mission in Afghanistan," 19.

71 Представитель Франции в Штаб-квартире союзных сил НАТО в Европе. Интервью автора Тинатин Агниашвили, Женева, Швейцария, март 2016. 
нако, Соглашение не было задействовано из-за различающихся позиций европейских стран, что еще раз подчеркивает актуальность исследовательской гипотезы в этой работе. ЕС нужно было официально отправить запрос НАТО о применении соглашения "Берлин плюс», но в случае с Ливией этого не случилось.

Ливийский кризис случился на пороге Европы, сделав Европу уязвимой от угроз с Юга. Кроме того, ощущение неотложности было очевидным НАТО, ЕС и отдельные государства чувствовали ответственность за своевременное предприятие конкретных действий. В итоге, во время ливийского кризиса были спроектированы четыре операции, и три из них были задействованы: операция «Заря Одиссея» под руководством коалиционных сил, операция НАТО «Объединенный защитник» и гражданская миссия EC EUBAM Ливия вступили в силу, а военная операция EC EUFOR осталась за кулисами.

Чтобы понять сложность кризиса, важно рассмотреть позиции иностранных акторов, государств и институций.

Операция в Ливии получила мандат ООН и поддержку региональных организаций, поэтому события развивались быстро. Ливийский кризис был «одним из кусочков более широкого пазла 'Арабской весны'». ${ }^{72}$ После восстания против режима Муаммара Каддафи ${ }^{73}$ в 2011, Арабская лига приняла резолюцию, ${ }^{74}$ призывающую Совет безопасности ООН (СБООН) предпринять все необходимые меры и установить зону, запрещенную для полетов. После начала революции и гибели 2000 гражданских лиц, ${ }^{75} 17$ марта СБООН принял резолюцию об установлении «запрещенной для полетов зоны» над Ливией и разрешил использование всех необходимых средств для защиты гражданского населения. ${ }^{76}$

Европейские страны, такие как Соединенное Королевство и Франция, были первыми, кто начал выполнять резолюции ООН. 19 марта началась операция "Заря Одиссея» ${ }^{77}$ под надсмотром США и с поддержкой европейских стран. Следовательно, она демонстрировала политическую волю и готовность Франции и Соединенного Королевства принять на себя

72 Maxime H.A. Larivé, Debating European Security and Defense Policy: Understanding the Complexity (Farnham, Burlington: Ashgate Publishing Company, 2014), 209.

73 Там же.

74 Joel Peters, ed., The European Union and the Arab Spring: Promoting Democracy and Human Rights in the Middle East (Lanham, MD: Lexington Books, 2012), 40.

75 Florence Gaub, The North Atlantic Treaty Organization and Libya: Reviewing Operation Unified Protector (Carlisle, PA: Strategic Studies Institute and U.S. Army War College Press, 2013), 2.

76 Security Council Resolution 1973 (2011) on Libya, по состоянию на 3 апреля 2016; www.nato.int/nato_static/assets/pdf/pdf_2011_03/20110927_110311-UNSCR1973.pdf.

77 Joe Quartararo, Sr., Michael Rovenolt, and Randy White, "Libya's Operation Odyssey Dawn: Command and Control," Prism 3, nо. 2, по состоянию на 2 апреля 2016, https://www.ciaonet.org/attachments/20162/uploads. 
ответственность за поддержание мира и безопасности в соседних странах. Несмотря на факт, что Соединенное Королевство считалось более «атлантическим» союзником, а Франция - более «европейским», их позиция была единой. Однако, это не было достаточным условием для того, чтобы весь ЕС выступил с единой и целостной позицией по поводу ливийского кризиса.

США отнеслись к кризису в Северной Африке очень осторожно и попытались получить юридический мандат на предпринимаемые действия. Они не квалифицировали проводимую в Ливии операцию как войну. ${ }^{78}$ Решающей была позиция страны привлечь НАТО и возглавить коалицию желающих. Однако, в случае с Ливией, многие критики утверждают, что США «руководили с задней линии». ${ }^{79}$

\section{Ливийский кризис и НАТО}

Можно указать на три основные причины для участия НАТО в ливийском кризисе, который не входил в его повестку дня в сфере безопасности: прежде всего, на участии Альянса настаивали по политическим причинам США (после того, как они сами включились); с оперативной точки зрения, активы НАТО были необходимы, и на стратегическом уровне, ЕС продемонстрировал ясное нежелание быть вовлеченным.

Важно отметить, что НАТО впервые за все время своего существования начало операцию против арабской страны. В отличие от ЕС, для НАТО Африка никогда не входила в орбиту его жизненно важных интересов. За его долгую историю, у Альянса было очень мало случаев участия в событиях на Африканском континенте.

Несмотря на этот факт, 31 марта 2011 года НАТО официально взяло на себя управление военной операцией в Ливии, проводимой на основании резолюций ООН, и начало осуществление операции «Объединенный защитник» (ОО3) с задачей наложить оружейное эмбарго, установить запрещенную для полетов зону и защитить гражданское население от нападений или от угрозы нападений. ${ }^{80}$ В рамках ОО3, 2/3 боевых заданий были выполнены Францией и Соединенным Королевством, а остальные Италией, Канадой, Данией, Норвегией, Швецией и Бельгией. ${ }^{81} \mathrm{~K}_{\text {операции }}$ были привлечены и региональные акторы, но в ограниченной степени: Объединенные Арабские Эмираты, Иордания и Катар ${ }^{82}$ в основном остались в роли поддержки. В ходе операции использовались только военно-

78 Gaub, The North Atlantic Treaty Organization and Libya, 4.

79 Patricia A. Weitsman, Waging War, Alliances, Coalitions and Institutions of Interstate Violence (Stanford: Stanford University Press, 2014), 177.

80 NATO, "Operation Unified Protector: Final Mission Stats," по состоянию на 12 апреля 2016, http://www.nato.int/nato_static_fl2014/assets/pdf/pdf_2011_11/ 20111108_111107-factsheet_up_factsfigures_en.pdf.

81 Gaub, The North Atlantic Treaty Organization and Libya, 7.

82 Там же. 
воздушные и военно-морские способности Альянса и отдельных странчленов, и ООЗ была официально завершена 31 октября $2011 .^{83}$

ООЗ выполнила свою миссию, заданную ООН, без человеческих потерь, и поэтому ее можно принимать за успешную операцию. Мандат ООЗ не включал смену режима в Ливии и участие НАТО в постконфликтных восстановительных работах. С юридической точки зрения, резолюции ООН и концепция «Ответственность за защиту» (на которую впервые сослался СБООН при единодушном голосовании) ${ }^{84}$ легитимировали ангажемент Альянса в Ливии.

Непосредственные цели операции были достигнуты за короткий срок, но в среднесрочном и долгосрочном плане Ливия оказалась далеко от установления мира и стабильности. Режим полковника Каддафи был свергнут, милиции взяли на себя ответственность за обеспечение безопасности, а нестабильность усиливалась изо дня в день. ${ }^{85}$ Многие критики характеризуют участие НАТО в Ливии скорее как "войну по выбору», чем «войну по необходимости». ${ }^{86}$

\section{EC и Ливия}

После установления НАТО запрещенной для полетов зоны, ЕС почувствовал, что от него ожидается «каким-то образом» способствовать стабилизации кризиса у своих ворот и продемонстрировать единство Европы. За спроектированной ЕС военной операцией последовала гражданская миссия в Ливии, но почти без успеха.

В апреле 2011 года, Европейский Совет принял решение начать военную операцию EUFOR Ливия для поддержки гуманитарных операций в Ливии. ${ }^{87}$ Однако, EUFOR могла быть активирована только на основании запроса Управления ООН по гуманитарным вопросам, ${ }^{88}$ который такой запрос вообще не рассматривал по причинам, связанным с безопасностью на месте. Прекращение EUFOR в большой степени подорвало доверие к способности ОПБО возглавлять и проводить эффективные военные операции по соседству.

По истечение двух лет, попытки ЕС все еще продолжались, и в 2013 году это привело к проекту новой гражданской миссии EUBAM Ливия ${ }^{89}$ Интегрированной миссии по оказанию пограничной помощи под эгидой

83 NATO, "Operation UNIFIED PROTECTOR: Final Mission Stats."

84 Weitsman, Waging War: Alliances, Coalitions and Institutions of Interstate Violence, 184.

85 Gaub, The North Atlantic Treaty Organization and Libya, 28.

86 Там же, 3.

87 “EUFOR Libya," по состоянию на 3 марта 2016, http://eeas.europa.eu/archives/ csdp/missions-and-operations/eufor-libya/index_en.htm.

88 Larivé, Debating European Security and Defense Policy, 209.

89 "EU Border Assistance Mission (EUBAM) in Libya," по состоянию на 3 марта 2016, http://eeas.europa.eu/csdp/missions-and-operations/eubam-libya/index_en.htm. 
ОПБО. Штаб-квартира миссии была в Триполи, но из-за ухудшающихся условий безопасности, с августа 2014 года EUBAM работает из Туниса, причем с очень ограниченными функциями. ${ }^{90}$

ЕС, и в частности, ОПБО, критиковали, главным образом, за неспособность реагировать на ливийский кризис своевременно и адекватно. Высокие ожидания по поводу участия ЕС в Ливии обуславливались внутренними и внешними факторами: специальным отношением ЕС к Африке, возросшими амбициями ОПБО после Лиссабона и существованием соглашения «Берлин плюс» в качестве юридического средства разделения труда между ЕС и НАТО. С внешней точки зрения, были налицо юридические инструменты (резолюции ООН), поддержка со стороны региональных организаций (Арабской лиги) и нежелание США возглавить операции.

После создания ОПБО, ЕС был очень активным на Африканском континенте. Из семнадцати ${ }^{91}$ продолжающихся в настоящее время миссий девять осуществляются в Африке. ЕС уже осуществил пятнадцать миссий, из которых восемь операций (гражданские и военные) были проведены на Африканском континенте. ${ }^{92}$ Проведение большинства операций ОПБО в Африке является яркой демонстрацией специального отношения ЕС к этому континенту. Кроме того, эта статистика показывает способность ЕС эффективно проводить военные операции, когда имеется налицо политическая воля, и предоставлять гражданские активы для процесса миростроительства и миротворчества в странах, где это нужно.

Другим важном фактором является доверие к ОПБО. С момента, когда Лиссабонский договор вступил в силу в 2009 году, ${ }^{93}$ ливийский кризис был самой большой угрозой на заднем дворе Европы. Этот договор нацелен на дальнейшее укрепление способностей ЕС в сфере внешней политики и безопасности. Несмотря на возросшие амбиции ЕС, по истечение двух лет оказалось, что он не очень эффективно способствует процессу установления мира, обеспечивает соответствующую военную помощь и консолидирует позиции стран-членов, когда это нужно.

Третьим важным фактором является существование соглашения «Берлин плюс». Если у ЕС не хватало потенциала предпринять военную операцию в Ливии, он мог бы настоять на активации инструмента для разделения обязанностей с НАТО. Но со стороны ЕС официально такой запрос не был сделан. Основная причина этой проблемы лежит в расходящихся позициях европейских стран в отношении ОПБО. Совершенным примером этого является политика Германии в этом плане.

90 Там же.

91 "Ongoing Missions and Operations."

92 Там же.

93 European Union, Treaty of Lisbon, 2007, по состоянию на 3 марта 2016, http://eurlex.europa.eu/legal-content/EN/TXT/?uri=uriserv\%3Aai0033. 
С самого начала стадии планирования, Германия была против военной операции в Ливии и воздержалась от голосования резолюции по Ливии в СБООН вместе с Россией и Китаем. ${ }^{94}$ Критически важными были экономические факторы, определяющие политическую позицию страны. В 2009 году Германия была одним из главных рынков для ливийского экспорта; ${ }^{95}$ кроме того, большинство из деловых контрактов были заключены с семьей Каддафи. Поэтому, Германия относилась скептически к участию в военной кампании против Ливии, и это решение имело общественную поддержку. 96

Между тем, на проведение первой военной операции в Ливии по политическим и связанным с безопасностью причинам настаивали другие европейские государства, Соединенное Королевство и Франция. В отличие от Германии, они были меньше заинтересованы в экономическом сотрудничестве с Ливией. Интересна позиция Италии, которая сначала отказалась от введения санкций против Ливии из-за своих торговых отношений и деловых контрактов, но позже «с нежеланием присоединилась к Франции и Соединенному Королевству, когда стало очевидным, что военная операция неизбежна». ${ }^{97}$

Эти разные подходы к политике безопасности ЕС очевидно подрывают доверие к ОПБО и указывают на несколько существенных недостатков: некогерентность европейских институций, отсутствие необходимых способностей и первенство национальных интересов над институциональными целями проистекают из расходящихся позиций европейских стран.

В целом, сотрудничество ЕС и НАТО в Ливии было бы логичным, адекватным и эффективным в плане расходов. Однако, оно даже не обсуждалось на официальном уровне из-за разнонаправленных позиций европейских стран и неспособности прийти к общей позиции.

\section{Актуально ли все еще соглашение "Берлин плюс»?}

После ливийского кризиса адекватность и актуальность соглашения «Берлин плюс» снова были поставлены под сомнением. Соглашение не было активировано с декабря 2004, хотя необходимость в распределении бремени между институциями в этом сложном мире очевидна.

Соглашение «Берлин плюс», как формат сотрудничества, на первом месте было задумано для Балкан. Европейские страны чувствовали себя под угрозой из-за нестабильности у своих ворот. С точки зрения НАТО и США, соглашение было удобной возможностью сохранить присутствие на Балканах и принять участие в продолжающейся операции через Штаб-квартиру союзных сил в Европе (SHAPE).

94 Koutrakos, The EU Common Security and Defense Policy, 131.

95 Peters, ed., The European Union and the Arab Spring, 42.

96 Там же.

97 Там же. 
Продолжительные дискуссии о дальнейшей активации соглашения имели место все эти годы, конкретных результатов не было. Более того, в 2005 году была выдвинута идея соглашения «Берлин плюс наоборот», 98 которое предполагало использование гражданских активов и способностей ЕС в операциях НАТО по менеджменту кризисов.

Следовательно, соглашение «Берлин плюс» не было применено еще раз по двум причинам: внутренней и внешней. Как было уже упомянуто, «Берлин плюс» позволяет сотрудничество НАТО-ЕС только в военной сфере и при условии, что одна из организаций официально запросит его активацию. И здесь единство европейских стран имеет решающее значение. Как показало рассмотрение случаев с Ливией и Афганистаном, позиции стран-членов ЕС находятся в разнобое, и что касается внешней политики и политики безопасности, определяются национальными интересами. Поэтому внутренние проблемы ОПБО уменьшают вероятность дальнейшего применения соглашения. На внешнем уровне, даже если ЕС выступит с единой позиции, активация соглашения может тормозиться государствами, которые не являются двойными членами, Турцией и Кипром, и использованию будет мешать отсутствие общего между институциями стратегического видения.

В заключение можно сказать, что соглашение «Берлин плюс», являющееся единственной институциональной рамкой между организациями, существует в качестве инструмента, но не как эффективный инструмент, который можно использовать в будущем. С оперативной точки зрения оно все еще актуально (продолжающаяся операция «Алтея» в Боснии и Герцеговине). В юридическом плане, соглашение налицо и может быть задействовано, если будет принято такое решение. Но в политической и стратегической перспективе оно сталкивается с серьезными проблемами и остается скорее как фасад, чем как эффективный механизм.

\section{Заключение}

Современные угрозы и проблемы безопасности требуют и естественным образом подталкивают отношения НАТО-ЕС к более эффективному сотрудничеству. При преобладающем членстве стран Западного сообщества, дополнительным способностям и общей повестке дня, они могли бы существенно способствовать поддержанию мира и стабильности по всему свету. Тщательный анализ факторов, мешающих эффективному сотрудничеству между институциями, помог бы субъектам, определяющим политику, лучше справляться с этими вызовами.

В данной статье изучается влияние двойных и недвойных стран-членов на формирование взаимодействия между организациями, и идентифици-

98 Erwan Lagadec, Transatlantic Relations in the 21 Century: Europe, America and the Rise of the Rest (New York: Routledge, 2012), 120, 121. 
руются ключевые моменты в существующих стратегических, политических и юридических рамках сотрудничества.

В данной статье внимание сфокусировано на Турции и Кипре, из стран, недвойных членов, и сделан анализ, в какой степени двойные члены оказывают влияние на взаимодействие между организациями в случае Ливии и Афганистана.

В результате анализа изучаемых конкретных случаев можно сформулировать следующие выводы.

Некоторые из стран, недвойных членов, в угоду своим национальным интересам "держат институции в заложниках»; 99 Турция и Кипр, имеющие политические разногласия, используют «право на вето», и в определенной степени мешают сотрудничеству.

Некогерентная позиция стран, двойных членов, в отношении ОПБО, находит выражение в отсутствии общей стратегической концепции. ${ }^{100}$ Поэтому, фрагментированная позиция европейских стран в рамках ОПБО является корневой причиной для ограниченного сотрудничества между организациями. На практике, двойные члены даже не пытаются разработать единую, целостную и четкую политику ЕС по менеджменту кризисов, и им удобна существующая неопределенность отношений между институциями потому, что они не хотят ограничивать гибкое использование способностей этих организаций предпочтительным для них образом.

Изучение случаев Ливии и Афганистана ясно показало, что независимо от того, является ли угроза непосредственной или нет, находится ли она у ворот Европы или далеко от ее границ, необходимо ли сотрудничество в военной или невоенной областях, взаимодействие между организациями не очень эффективно. ЕС и НАТО занимаются конкретными кризисными ситуациями на ад-хок основе, не имея общего стратегического подхода.

Отсутствие разделения труда между институциями приводит к дублированию функций в определенной степени. Дублирование функций между институциями проистекает из экзогенных и эндогенных факторов: текущие ситуации кризисного менеджмента требуют одновременного использования гражданских и военных способностей; во внутреннем плане, из-за отсутствия разделения труда, организации пытаются развивать дополнительные способности (ЕС - военные, НАТО - гражданские), что приводит к дублированию.

Соглашение «Берлин плюс» все еще актуально на юридическом и оперативном уровнях, но устарело на стратегически-политическом уровне. Сотрудничество между институциями более успешно на театре операций, чем на стратегическом уровне.

99 Howorth, Security and Defence Policy in the European Union, 130.

100 Результаты голосования в Соединенном Королевстве о выходе из Европейского Союза являются еще одним ярким примером разнобоя в позициях европейских стран. 
Основываясь на результате анализа, можно утверждать, что ЕС и НАТО могут трансформировать свои отношения в более плодотворное и взаимовыгодное сотрудничество, если они обратят внимание на следующие моменты: ЕС следует разработать более четкие руководящие положения или политику по ОПБО, сконцентрированные в двух ключевых направлениях: (1). Определение области и условий, при которых задействуются операции/миссии ОПБО; (2). Обеспечение достаточных человеческих и логистических способностей своевременным и рациональным образом. Кроме того, ЕС следовало бы улучшить координацию между его структурами для плавного выполнения поставленных задач и достижения поставленных целей; попытаться разработать рамку для сотрудничества с НАТО более широкую, чем соглашение «Берлин плюс», которое, по своей сути, ограничивается только военным сотрудничеством. Обе институции должны мобилизовать усилия для разрешения кипрского вопроса способом, который был бы приемлемым для Турции и Кипра (Греции), и содействовать разработке совместного ЕС-НАТО стратегического видения с четким разделением ответственностей. Следовательно, в существующем сложном ландшафте безопасности есть большая потребность в распределении бремени между ЕС и НАТО. Более того, имеется жизнеспособный потенциал обеих институций давать свой вклад в менеджмент кризисов более эффективным и результативным способом. Поэтому, во имя мира и стабильности «ЕС и НАТО должны и могут играть взаимно дополняющиеся и взаимно усиливающиеся роли». ${ }^{101}$

\section{ПРИЛОЖЕНИЕ А}

Члены НАТО, не являющиеся членами ЕС: Албания, Канада, Исландия, Норвегия, Турция, США.

Члены EC, не являющиеся членами НАTO: Австрия, Кипр, Финляндия, Ирландия, Мальта, Швеция.

Двойные члены: Бельгия, Болгария, Хорватия, Чешская Республика, Дания, ${ }^{102}$ Эстония, Франция, Германия, Греция, Венгрия, Италия, Латвия, Литва, Люксембург, Нидерланды, Польша, Португалия, Румыния, Словакия, Словения, Испания, Соединенное Королевство.

${ }^{101}$ NATO, "Active Engagement, Modern Defence - Strategic Concept for the Defence and Security of the Members of the North Atlantic Treaty Organization," по состоянию на 11 апреля 2016, www.nato.int/strategic-concept/pdf/Strat_Concept_ web_en.pdf.

102 Дания отказалась от ЕПБО; Stephanie С. Hofmann, “Overlapping Institutions in the Realm of International Security: The Case of NATO and ESDP," Perspectives on Politics 7, no. 1 (March 2009): 45-52. 


\section{2 общих члена}

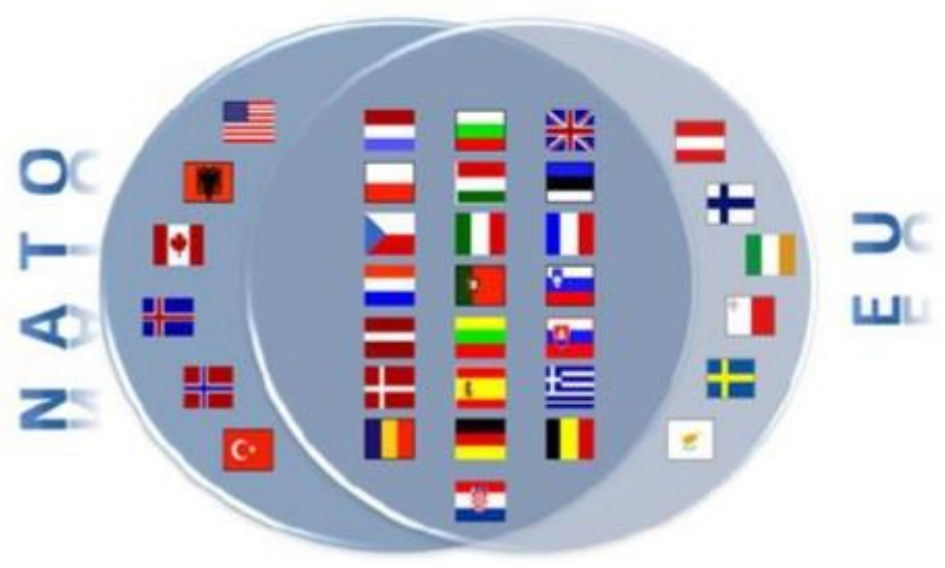

\section{Об авторе}

Госпожа Тинатин Агниашвили имеет обширный профессиональный опыт по вопросам безопасности. С 2007 года она занимала разные должности в Департаменте евроатлантической интеграции Министерства обороны Грузии. С 2013 года она возглавляет Отдел интеграции с НАТО и приносит большой вклад в осуществление успешного сотрудничества между Грузией и НАТО. Госпожа Агниашвили получила степень бакалавра по международным отношениям в 2005 году и степень магистра по международным отношениям в Тбилисском государственном университете, а также степень магистра в сфере исследований по вопросам международной и европейской безопасности в Университете Женевы в 2016. Госпожа Агниашвили посещала долгосрочные курсы, связанные с безопасностью и обороной в Тартуском университете, в Европейском центре исследований по вопросам безопасности имени Джорджа К. Маршалла и в Женевском центре политики безопасности. Госпожа Агниашвили читает лекции в государственных и частных университетах по разным вопросам международных дел. Она владеет английским и русским языками.

E-mail: taghniashvili@mod.gov.ge. 